\title{
O Litoral do Paraná: entre a riqueza natural e a pobreza social ${ }^{*}$
}

\section{Paraná coast: between natural wealth and social poverty}

\author{
Naína Pierri ESTADES ${ }^{* *}$
}

\section{RESUMO}

O litoral paranaense possui uma natureza extensa, biodiversa e de beleza singular. A realidade social da região é diversa e contrastante. Vastas áreas de conservação, escassamente povoadas, coexistem com uma grande cidade portuária e balneários urbanos que crescem a ritmos vertiginosos. A dinâmica regional, que atrai crescentes contingentes de população de outras regiões do estado e de estados vizinhos, mostra-se insuficiente para superar a pobreza. Ao mesmo tempo, as múltiplas leis de proteção à natureza resultam ineficazes para evitar os crescentes impactos ambientais. $O$ artigo traz informações socioeconômicas recentes, analisadas por grupos de municípios, visando compreender os elementos mais específicos que operam na reprodução da pobreza e dos impactos ambientais.

Palavras-chave: população, pobreza, meio ambiente e desenvolvimento.

\begin{abstract}
The coast of Paraná presents natural ecosystems that are extensive, diverse, and with unique beauty. Its social reality is diverse and contrasting. Vast areas under conservation, scarcely populated, coexist with a big port city, and beach resorts with very rapid growth rates. This regional dynamics, which attracts increasing numbers of population from other regions of the state and from other nearby states, is not enough to alleviate poverty. At the same time, the profuse environment protection laws are inefficient to avoid increasing environmental degradation. This paper offers recent socio-economic data, which are analyzed by groups of municipalities, aiming at understanding the specific elements that operate in the reproduction of poverty and environmental impacts.

Key-words: population, poverty, environment and development.
\end{abstract}

* Agradecemos, especialmente, a colaboração da Ec. M. Deschamps, do Ipardes.

** Socióloga. Doutora em Meio Ambiente e Desenvolvimento pela Universidade Federal do Paraná - UFPR. Professora visitante no Centro de Estudos do Mar daUFPR.<naina@cem.ufpr.br> 


\section{Introdução}

Quando se caracteriza o litoral paranaense, a literatura fala de um lugar com grande heterogeneidade ambiental e socioeconômica, e com fortes paradoxos. Os principais elementos que fazem a heterogeneidade são a grande variedade de ecossistemas, a diversidade de atividades econômicas com graus distintos de desenvolvimento, a variedade cultural de populações de origem e trajetórias históricas diferentes e as fortes desigualdades sociais. Quanto aos paradoxos, coloca-se que se trata de uma região com valiosos remanescentes naturais, objeto de uma ampla bateria de disposições legais para protegê-los, mas com crescentes níveis de degradação; que existe grande potencial econômico e atividades em expansão, mas, no conjunto, a região permanece subdesenvolvida; e que, sendo uma das regiões mais pobres do estado, tem se constituído na última fronteira de ocupação, onde chegam grandes contingentes de imigrantes, na esperança de melhorar sua vida (ANDRIGUETTO; MARCHIORO, 2002, p. 159-160).

Esta situação, que imbrica falta de desenvolvimento, pobreza, desigualdade social e danos ou ameaças a valiosos recursos naturais, remete à problemática geral contemporânea frente à qual se postula a alternativa do desenvolvimento sustentável como um modelo-meta que articule o crescimento econômico com melhora das condições de vida da população e responsabilidade ambiental. Assim colocado, supera-se a visão tradicional de interpretar estes problemas no quadro de uma oposição homemnatureza onde o homem é visto como intrinsecamente destrutivo, para uma outra visão que considera que a relação homem-natureza está mediada social e historicamente, e que por isso busca explicar os problemas ambientais como expressão de problemas entre os homens, quer dizer, das relações sociais presentes.

Neste artigo, foram organizadas algumas informações socioeconômicas com o intuito de contribuir para a compreensão das dinâmicas sociais que, entre outras coisas, expressam-se nos processos de ocupação do solo e nas formas de uso dos recursos presentes, assim como nos limites para evitar ou mitigar os problemas gerados.
Mais concretamente, focalizam-se os processos demográficos de crescimento da população permanente, sua origem e distribuição espacial. Resenhamos a história econômica e descrevemos em números a economia regional atual, focando as diferentes realidades municipais e as capacidades setoriais de geração de emprego. Indagamos, depois, a pertinência das expectativas dos imigrantes por meio da análise da distribuição de renda da população local e sua comparação com a distribuição de renda da população do estado e da Região Metropolitana de Curitiba, RMC. Finalmente, vemos as pautas da espacialização dos imigrantes recentes e os problemas socioambientais decorrentes.

\section{Metodologia}

As classificações demográficas consideram que os municípios do litoral formam a Microrregião Homogênea de Paranaguá, por sua vez inserida na Mesorregião Metropolitana de Curitiba. ${ }^{.}$E, dentro da Microrregião, diferencia-se o grupo constituído pelos municípios de Paranaguá, Guaratuba, Matinhos e Pontal do Paraná, por formar o que chamam de "ocupação urbana contínua". Sem pretender questionar a pertinência técnica das classificações que destacam fatores de homogeneidade nem os critérios para abordar como uma unidade de estudo o conjunto desses quatro municípios, nós preferimos trabalhar a idéia de múltiplas heterogeneidades e buscamos agrupar os municípios do litoral em função de diferenças e semelhanças que nos pareceram facilitadoras para a compreensão das dinâmicas sociais presentes. Nesse sentido, tomando as realidades funcionais construídas historicamente sobre especificidades naturais, propomos distinguir três grupos de municípios: os portuários (Paranaguá e Antonina); os rurais (Morretes e Guaraqueçaba); e os praiano-turísticos (Guaratuba, Matinhos e Pontal do Paraná). Esta classificação destaca o elemento econômico mais marcante da história recente ou que, sem ser muito recente, explica em grande parte a situação atual. Mas não se pretende negar a existência de outras atividades em cada município nem se postulam equivalências entre os municípios de cada tipo.

1 Microrregiōes Homogêneas, segundo o IBGE, são áreas que agrupam, dentro de um mesmo estado, municípios com características físicas, sociais e econômicas de certa homogeneidade. Mesorregiōes são unidades homogêneas em nível intermediário entre as microrregiões e o estado.

2 Chama-se Ocupação Contínua, segundo o Ipardes, um espaço urbano que reúne municípios contíguos com crescimento populacional acima da média estadual, funcionalmente integrados nos aspectos social e econômico. 
Então, depois da descrição de alguns elementos gerais, analisaremos a informação seguindo esta classificação.

A informação utilizada se baseia na revisão bibliográfica da literatura disponível e nos dados secundários mais recentes, produzidos por diversos órgãos públicos. Optou-se por construir os quadros mantendo certo detalhe, a fim de disponibilizar os dados.

\section{Dados gerais}

O conjunto dos sete municípios litorâneos representa apenas 3\% da superfície do Paraná. Por sua vez, o tamanho dos municípios é bastante desigual, sendo Matinhos o menor, com $111,5 \mathrm{~km}^{2}$ (2\% do total); e o maior, Guaraqueçaba, com 2.159,3 km² (35\% do total) (quadro 1).

Até meados do século XVII, a área total pertencia ao estado de São Paulo, tendo-se desmembrado como uma unidade administrativa, sob o nome de Paranaguá, em 1648. Os municípios atuais restantes foram se desprendendo de Paranaguá, sendo que Antonina e Morretes o fizeram em meados do século XIX e os demais, no século XX: Guaraqueçaba e Guaratuba, no ano de 1947; Matinhos, em 1968; e Pontal do Paraná, em 1997.

São municípios muito próximos à capital do estado. Considerando a distância entre as sedes municipais, o mais próximo é Antonina, a $63 \mathrm{~km}$ de Curitiba, e o mais distante, Guaraqueçaba, a $158 \mathrm{~km}$; entretanto, a efetiva acessibilidade depende, em maior medida, da existência de vias adequadas de transporte, as quais têm grande importância como elementos dinamizadores/inibidores de distintas atividades e usos do espaço.

A população permanente atual (2000) se distribui de forma muito desigual entre os municípios, o que, combinado com a desigualdade de superfícies, resulta em densidades bem diferentes. Os municípios rurais, com quase a metade da superfície total (46\%), são habitados por $10 \%$ da população; os municípios portuários, com pouco mais da quarta parte da superfície total $(27 \%)$, detêm $62 \%$ da população; e os municípios praianos, com a restante quarta parte da superfície, detêm $28 \%$ da população. Mais detalhadamente, temos, nos extremos, Paranaguá, com apenas $11 \%$ da superfície total e $54 \%$ dos habitantes (127.339), e Guaraqueçaba, com 35\% da superfície total e apenas $4 \%$ da população (8.288 habitantes). A densidade populacional média é de $38 \mathrm{hab} /$ $\mathrm{km}^{2}$, mas varia entre $4 \mathrm{hab} / \mathrm{km}^{2}$, em Guaraqueçaba, e 217 $\mathrm{hab} / \mathrm{km}^{2}$, em Matinhos, seguido por Paranaguá, com 191 $\mathrm{hab} / \mathrm{km}^{2}$ (quadro 2).

Cabe destacar que a questão populacional do litoral não se limita à população permanente. A afluência de turistas, particularmente nos municípios praianos, constitui um fenômeno importante que tem lugar durante o ano todo, mas que se concentra no verão e se intensifica nas festas de fim de ano e Carnaval. A afluência em temporada está estimada em 1,5 milhão de pessoas, ${ }^{3}$ o que multiplica a população de todo o litoral por mais de 6 vezes e a

QUADRO 1 - MUNICÍPIOS DO LITORAL PARANAENSE - DATA DE INSTALAÇÃO, JURISDIÇÕES ANTERIORES, DISTÂNCIA DA CAPITAL DO ESTADO, SUPERFÍCIE

\begin{tabular}{|c|c|c|c|c|c|}
\hline \multirow[t]{2}{*}{ Municípios } & \multirow[t]{2}{*}{ Data de instalação } & \multirow{2}{*}{$\begin{array}{l}\text { Jurisdições anteriores à } \\
\text { instalação }\end{array}$} & \multirow{2}{*}{$\begin{array}{c}\text { Distância entre a capital e a } \\
\text { sede municipal } \\
(\mathrm{Km})\end{array}$} & \multicolumn{2}{|c|}{ Superfície } \\
\hline & & & & $\mathbf{K m}^{2}$ & $\%$ \\
\hline $\begin{array}{l}\text { PORTUÁRIOS } \\
\text { Paranaguá } \\
\text { Antonina }\end{array}$ & $\begin{array}{l}26 / 12 / 1648 \\
21 / 01 / 1857\end{array}$ & $\begin{array}{c}\text { Estado de São Paulo } \\
\text { Paranaguá }\end{array}$ & $\begin{array}{l}84 \\
63\end{array}$ & $\begin{array}{l}665,8 \\
968,8\end{array}$ & $\begin{array}{l}11 \\
16\end{array}$ \\
\hline $\begin{array}{c}\text { RURAIS } \\
\text { Morretes } \\
\text { Guaraqueçaba }\end{array}$ & $\begin{array}{l}05 / 07 / 1841 \\
31 / 10 / 1947\end{array}$ & $\begin{array}{l}\text { Antonina } \\
\text { Paranaguá }\end{array}$ & $\begin{array}{c}65 \\
158\end{array}$ & $\begin{array}{c}686,5 \\
2.159,3\end{array}$ & $\begin{array}{l}11 \\
35\end{array}$ \\
\hline $\begin{array}{c}\text { PRAIANO-TURÍSTICOS } \\
\text { Guaratuba } \\
\text { Matinhos } \\
\text { Pontal do Paraná } \\
\end{array}$ & $\begin{array}{l}25 / 10 / 1947 \\
19 / 12 / 1968 \\
01 / 01 / 1997 \\
\end{array}$ & $\begin{array}{l}\text { Paranaguá } \\
\text { Paranaguá } \\
\text { Paranaguá }\end{array}$ & $\begin{array}{l}111 \\
103 \\
112\end{array}$ & $\begin{array}{c}1.326,8 \\
111,5 \\
216,2 \\
\end{array}$ & $\begin{array}{r}21 \\
2 \\
4 \\
\end{array}$ \\
\hline TOTAL & & & & $6.135,4$ & 100 \\
\hline
\end{tabular}

FONTE: Dados de instalaçāo e origem: Ipardes, 2003: distância da capital: apud Ipardes, 2003: dados de superfície: Sema, idem.

3 Essa é a quantidade mais referida na literatura, mas é uma informação incerta. Não se sabe se se refere à vinda total de turistas ao longo do verão ou aos momentos picos. Nunca se especifica a fonte nem o procedimento aplicado para fazer a estimativa e nem a sua data. Uma bibliografia recente (2002) apresenta a mesma quantidade de materiais de cinco anos atrás, não sendo possível determinar se é porque as quantidades reais permanecem constantes ou porque simplesmente se repete o dado. Aparentemente, são dados estimados em função do fluxo de carros na BR 277 , levantados pela empresa administradora do pedágio. 
dos municípios praianos por 23 vezes. Se a densidade desses municípios, considerando a população permanente, é de $40 \mathrm{hab} / \mathrm{km}^{2}$ (2000), essa quantidade de turistas supõe $946 \mathrm{hab} / \mathrm{km}^{2} .{ }^{4}$ Obviamente, isso implica um choque periódico de múltiplas consequiências ambientais e sociais, que deve ser considerado para dar adequada conta da realidade litorânea.

\section{Evolução demográfica do litoral nos últimos 30 anos (1970-2000)}

Nos últimos 30 anos, a população do litoral paranaense foi duplicada, passando de 112.310 habitantes, em 1970, a 235.840, em 2000, a uma taxa média de crescimento anual de 2,25\%. Essa dinâmica tem apresentado taxas altas e crescentes: 2,01\%a.a., entre 1970 e 1980; 2,25\%a.a., entre 1980 e 1991; e 3,39\%a.a., entre 1991 e 2000 , acima do crescimento vegetativo e das taxas observadas para o estado, o que se visualiza na evolução da participação da região no total da população do Paraná. Esse crescimento tem sido predominantemente urbano, de forma que a taxa de urbanização passou de $69 \%$, em 1970, a $89 \%$, em 2000 , enquanto a estadual, nesta última data, foi de aproximadamente $81 \%$, similar à do Brasil como um todo (quadro 3 ). Estes dados permitem antecipar que a região não deixará de crescer nos próximos anos, ainda que num ritmo mais lento.

Observando a evolução do crescimento populacional e das taxas de urbanização, por município, entre 1970 e
2000 , ressalta-se a não homogeneidade temporal e espacial, tanto entre municípios como entre as áreas urbanas e rurais (quadro 4 ).

No caso dos municípios portuários, em 1970, Paranaguá já concentrava a metade da população do litoral (62.327 habitantes) e detinha a maior taxa de urbanização $(84 \%)$. Cresceu a uma taxa média de 2,16\%a.a. ou um pouco mais na década de 70 e menos na seguinte. Sua taxa de urbanização chegou, em 2000, a 96\%. Por sua vez, Antonina, partindo de uma população de 16.448 habitantes em 1970, teve uma taxa média de crescimento anual muito baixa (0,46\%a.a.), com taxa negativa nos anos 70 e uma leve recuperação até 2000 , que atingiu $1,29 \%$ a.a. Sua taxa de urbanização passou de $70 \%$, em 1970, a $83 \%$, em 2000.

Os municípios de Morretes e Guaraqueçaba apresentam taxas de crescimento muito baixas, relativamente estáveis, e são os únicos onde a maior parte da população se manteve no meio rural em todo o período, mas, com taxas de urbanização progressivamente maiores. Morretes, partindo de uma população de 11.836 habitantes, em 1970 , cresceu a uma taxa média de $0,77 \%$ a.a., registrando crescimento negativo na década de 80 ; e Guaraqueçaba, partindo de uma população inicial de 7.848 habitantes, teve um crescimento de $0,24 \%$ a.a., com taxa negativa na década dos 70. Quanto às taxas de urbanização, Morretes passou de $34 \%$, em 1970, a 47\%, em 1991, mantendo-se igual em 2000; e Guaraqueçaba, passou de $18 \%$ a $31 \%$ entre 1970 e 2000 .

Os municípios praiano-turísticos, que em 1970 eram somente Guaratuba e Matinhos, já que Pontal do Paraná

QUADRO 2 - MUNICÍPIOS DO LITORAL PARANAENSE, 2000 - POPULAÇÃO, SUPERFÍCIE, E DENSIDADE POPULACIONAL.

\begin{tabular}{|c|c|c|c|c|c|}
\hline \multirow[b]{2}{*}{ Municípios } & \multicolumn{2}{|c|}{ População } & \multicolumn{2}{|c|}{ Superfície } & \multirow{2}{*}{$\begin{array}{c}\text { Densidade populacional } \\
\mathrm{Hab} / \mathrm{km}^{2}\end{array}$} \\
\hline & Hab. & $\%$ & $\mathrm{Km}^{2}$ & $\%$ & \\
\hline PORTUÁRIOS & 146.513 & 62 & $1.634,6$ & 27 & 90 \\
\hline Paranaguá & 127.339 & 54 & 665,8 & 11 & 191 \\
\hline Antonina & 19.174 & 8 & 968,8 & 16 & 20 \\
\hline RURAIS & 23.563 & 10 & $2.845,8$ & 46 & 8 \\
\hline Morretes & 15.275 & 6 & 686,5 & 11 & 22 \\
\hline Guaraqueçaba & 8.288 & 4 & $2.159,3$ & 35 & 4 \\
\hline PRAIANO-TURÍSTICOS & 65.764 & 28 & $1.654,5$ & 27 & 40 \\
\hline Guaratuba & 27.257 & 12 & $1.326,8$ & 21 & 21 \\
\hline Matinhos & 24.184 & 10 & 111,5 & 2 & 217 \\
\hline Pontal do Paraná & 14.323 & 6 & 216,2 & 4 & 66 \\
\hline TOTAL & 235.840 & 100 & $6.135,4$ & 100 & 38 \\
\hline
\end{tabular}

FONTE: População: IBGE - Censo 2000. Dados de superfície: Sema, apud Ipardes, 2003. 
QUADRO 3 - LITORAL PARANAENSE, 1970 A 2000 - POPULAÇÃO E TAXAS DE CRESCIMENTO ANUAL POR SITUAÇÃO DE DOMICÍlIO. TAXA DE URBANIZAÇÃO E PARTICIPAÇÃO NA POPULAÇÃO DO ESTADO.

\begin{tabular}{|c|c|c|c|c|c|c|c|c|}
\hline \multirow[b]{2}{*}{ Municípios } & \multicolumn{4}{|c|}{ População } & \multicolumn{4}{|c|}{ Taxas anuais médias de crescimento } \\
\hline & 1970 & 1980 & 1991 & 2000 & $1970 / 80$ & $1980 / 91$ & $1991 / 00$ & $1970 / 00$ \\
\hline TOTAL & 112.310 & 137.019 & 174.965 & 235.840 & 2,01 & 2,25 & 3,39 & 2,25 \\
\hline Urbano & 77.865 & 104.768 & 141.528 & 209.224 & 3,01 & 2,77 & 4,39 & 3,01 \\
\hline Rural & 34.445 & 32.251 & 33.437 & 26.616 & $-0,66$ & 0.33 & $-2,48$ & $-0,77$ \\
\hline Taxa urbanização \% & 69 & 76 & 81 & 89 & & & & \\
\hline Participação relativa no Estado \% & 1,6 & 1,8 & 2,1 & 2,5 & & & & \\
\hline
\end{tabular}

FONTE: IBGE - Censos demográficos 1970 - 2000.

ainda estava sob jurisdição de Paranaguá, apresentam interessantes diferenças na origem. Matinhos tinha a metade da população de Guaratuba (4.317 em relação a 9.734), mas uma taxa de urbanização bem maior (73\% em relação a 59\%). Observando a evolução posterior, o que é mais chamativo é que ambos começaram com taxas médias anuais de crescimento semelhantes na década de 70 , de $2,77 \%$ a.a. e 2,27\%a.a., respectivamente, equivalentes à de Paranaguá, mas cresceram fortemente nos períodos seguintes: enquanto em Guaratuba a taxa chegou a 4,67\%a.a. entre 1991 e 2000, em Matinhos, chegou a $8,7 \%$ a.a., levando sua população a 24.184 habitantes, quase $90 \%$ da população atingida em Guaratuba. No que diz respeito à urbanização, Matinhos manteve a vantagem em relação à Guaratuba, chegando ao extremo de uma taxa de $99 \%$ em 2000, enquanto Guaratuba chegou à taxa de $85 \%$, na mesma data. Por último, o novo município de Pontal de Paraná, partindo de 5.577 habitantes em 1991, cresceu a uma taxa anual média de 10,93\%a.a., multiplicando sua população duas vezes e meia até o ano 2000, quando chegou a ter 14.323 habitantes. Sua taxa de urbanização era de $97 \%$ em 1991, e de $99 \%$ em 2000, igual à de Matinhos, sendo ainda maiores que a de Paranaguá.

No conjunto, o que mais se destaca é este abrupto e constante crescimento da população permanente dos municípios praianos, que resulta maior no sentido Sul-Norte, seguindo o avanço da ocupação com fins turísticos. $\mathrm{E}$, em segundo lugar, o persistente crescimento de Paranaguá, que tem lhe permitido se manter, nestes últimos 30 anos, com mais da metade da população do litoral.

\section{A imigração como principal origem do crescimento demográfico do litoral}

Em relação a fenômenos de forte crescimento populacional recente, como o descrito, descarta-se a possibilidade de que seja principalmente decorrente de processos endógenos de baixas taxas de mortalidade e altas taxas de fecundidade em função das tendências atuais dos processos demográficos. Realmente o Brasil se caracteriza historicamente por altas taxas de crescimento populacional e, no século XX, o declínio da mortalidade iniciado nos anos 30 trouxe três décadas de acelerado crescimento, mas, a partir da metade dos anos 60 , as taxas de crescimento começaram a descer por conta da forte diminuição da taxa de fecundidade (HOGAN, 1997, p. 374) (quadro 5).

A taxa de fecundidade 5 apresentou tendência de declínio desde os anos 30 , que se acelerou a partir dos anos 60 por uma série de fatores, como a invenção da pílula anticoncepcional (1965), a crescente urbanização, e o avanço do feminismo, entre outros. Em 1930/35, a taxa era de 6,22 filhos/mulher em idade reprodutiva; em 1960/65, era de 6,00; e em 1987/92, de 2,58. Nas regiões densamente urbanizadas dos estados do Sul-Sudeste, as taxas de fecundidade se aproximam do nível de mera reposição ou ainda de níveis inferiores. No Paraná, essa taxa era de 6,51 filhos/ mulher em idade reprodutiva na década dos 50 , descendo a 2,34 no início dos 90, mais pronunciadamente no meio urbano que no rural (quadro 6). 
QUADRO 4 - MUNICÍPIOS DO LITORAL PARANAENSE, 1970 A 2000 - POPULAÇÃO E TAXAS DE CRESCIMENTO ANUAL POR SITUAÇÃO DE DOMICÍLIO.

\begin{tabular}{|c|c|c|c|c|c|c|c|c|}
\hline \multirow[b]{2}{*}{ Municípios } & \multicolumn{4}{|c|}{ População } & \multicolumn{4}{|c|}{ Taxas anuais crescimento } \\
\hline & 1970 & 1980 & 1991 & 2000 & $1970 / 80$ & $1980 / 91$ & $1991 / 00$ & $1970 / 00$ \\
\hline \multicolumn{9}{|l|}{ PORTUÁRIOS } \\
\hline Paranaguá & 62.327 & 81.974 & 102.098 & 127.339 & 2,78 & 2,02 & 2,46 & 2,16 \\
\hline Urbano & 52.125 & 72.066 & 89.257 & 122.347 & 3,29 & 1,96 & 3,53 & 2,60 \\
\hline Rural & 10.202 & 9.908 & 12.841 & 4.992 & $-0,29$ & 2,39 & $-9,87$ & $-2,12$ \\
\hline Taxa urbanização & 84 & 88 & 87 & 96 & 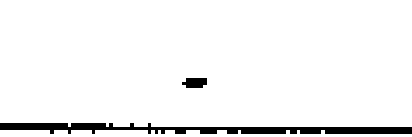 & & 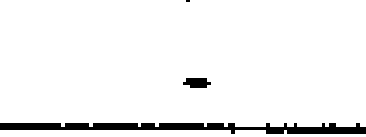 & - \\
\hline Antonina & 16.448 & 16.305 & 17.070 & 19.174 & $-0,09$ & 0,42 & 1,29 & $\mathbf{0 , 4 6}$ \\
\hline Urbano & 11.529 & 12.736 & 14.018 & 15.837 & 1,00 & 0,88 & 1,35 & 0,96 \\
\hline Rural & 4.919 & 3.569 & 3.052 & 3.337 & $-3,16$ & $-1,41$ & 0,99 & $-1,16$ \\
\hline Taxa urbanização & 70 & 78 & 82 & 83 & & & & \\
\hline \multicolumn{9}{|l|}{ RURAIS } \\
\hline Morretes & 11.836 & 13.238 & 13.135 & 15.275 & 1,13 & $-0,07$ & 1,67 & $\mathbf{0 , 7 7}$ \\
\hline Urbano & 3.995 & 5.747 & 6.194 & 7.153 & 3,70 & 0,68 & 1,60 & 1,76 \\
\hline Rural & 7.841 & 7.491 & 6.941 & 8.122 & $-0,46$ & $-0,69$ & 1,74 & 0,11 \\
\hline Taxa urbanização & 34 & 43 & 47 & 47 & & & & - \\
\hline Guaraqueçaba & 7.648 & 7.647 & 7.762 & 8.288 & $-0,001$ & 0,14 & 0,72 & 0,24 \\
\hline Urbano & 1.348 & 1.291 & 1.742 & 2.582 & $-0,43$ & 2,76 & 4,42 & 1,97 \\
\hline Rural & 6.300 & 6.356 & 6.020 & 5.706 & 0,09 & $-0,49$ & $-0,59$ & $-0,30$ \\
\hline Taxa urbanização & 18 & 17 & 22 & 31 & - & - & 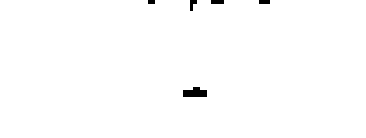 & - \\
\hline \multicolumn{9}{|l|}{ PRAIANOS-TURISTICOS } \\
\hline Guaratuba & 9.734 & 12.183 & 17.998 & 27.257 & 2,27 & 3,61 & 4,67 & 3,14 \\
\hline Urbano & 5.713 & 8.129 & 14.019 & 23.156 & 3,59 & 5,08 & 5,68 & 4,29 \\
\hline Rural & 4.021 & 4.054 & 3.979 & 4.101 & 0.08 & $-0,17$ & 0,33 & 0,06 \\
\hline Taxa urbanização & 59 & 67 & 78 & 85 & & $x_{1}$ & & . \\
\hline Matinhos & 4.317 & 5.672 & 11.325 & 24.184 & 2,77 & 6,49 & 8,70 & 5,31 \\
\hline Urbano & 3.155 & 4.799 & 10.866 & 24.000 & 4,28 & 7,71 & 9,11 & 6,28 \\
\hline Rural & 1.162 & 873 & 459 & 184 & $-2,82$ & $-5,68$ & $-9,57$ & $-5,38$ \\
\hline Taxa urbanização & 73 & 85 & 96 & 99 & - & - & - & - \\
\hline Pontal do Paraná & - & - & 5.577 & 14.323 & - & - & 10,93 & - \\
\hline Urbano & - & - & 5.432 & 14.149 & - & - & 11,11 & - \\
\hline Rural & - & - & 145 & 174 & - & - & 2,06 & - \\
\hline Taxa urbanização & 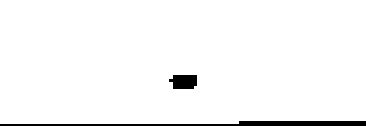 & - & 97 & 99 & - & - & - & - \\
\hline
\end{tabular}

FONTE: IBGE - Censos Demográficos 1970 - 2000.

Estes dados indicam como origem principal do crescimento populacional extraordinário, em períodos recentes, os processos de migração.

Os grandes movimentos migratórios no Brasil também têm mudado nos anos recentes. Até os anos 80 , caracterizavam-se por movimentar milhões de pessoas em grandes distâncias, na busca de uma inserção produtiva nas fronteiras agrícolas e nos grandes centros urbano-industriais com a expectativa de melhorar a vida. Mas, em função da diminuição das oportunidades nesses destinos, essa corrente migratória perdeu intensidade e se reforçou outra, que movimenta menor quantidade de pessoas em distâncias menores, atrás de oportunidades mais pontuais e na expectativa da simples sobrevivência. Cresceram, então, os movimentos intra-estaduais e entre estados vizinhos, frente à ocorrência de processos econômicos dinâmicos, ainda que pontuais, num estado ou região. O caso particular do crescimento da população dos balneários, constatado em toda a costa do país, tem sido interpretado como produto da procura de melhor qualidade de vida por parte de setores de classe média (profissionais e aposentados, entre outros) (DESCHAMPS; KLEINKE, 2000, p. 46-47).

No caso do Paraná, o principal movimento migratório continua sendo o esvaziamento rural e de pequenos centros urbanos, que leva a população a se concentrar na Região Metropolitana de Curitiba (RMC), assim como na aglomeração urbana do norte central do estado, liderada por Londrina e Maringá. Como esses lugares vêm oferecendo menos e piores oportunidades, ensaiam-se outros destinos, um dos quais é o litoral. Então (embora seja constatada a afluência de setores de classe média na procura de melhor qualidade de vida) o fenômeno mais pronunciado é o crescente fluxo de pessoas pobres, em idade produtiva, majoritariamente saídas do interior do estado ou da própria RMC, buscando oportunidades de trabalho e moradia. Isso estaria sendo induzido principalmente pelas expectativas geradas pela ex- 
pansão das atividades portuárias de Paranaguá e das atividades relativas ao turismo praiano; e favorecido pela proximidade do litoral à RMC, atraindo pessoas que moram nela e pessoas de mais longe, para as quais o litoral aparece como um destino melhor, mas de acessibilidade equivalente à da RMC (idem).

Os dados dos últimos censos verificam esses processos de imigração nos municípios do litoral, particularmente dirigidos a Paranaguá e aos municípios praianoturísticos. Em conjunto, esses quatro municípios receberam 14,5 mil imigrantes no período 1986/91 e 24,9 mil no período $1991 / 96$, o que representa um aumento de $71,4 \%$. Quanto à origem, a maioria veio do próprio estado e o restante, principalmente dos estados vizinhos de Santa Catarina e São Paulo (idem, p. 50).

Segundo dados do último censo, entre 1990 e 2000 , o litoral em conjunto recebeu 54.447 imigrantes. A importância desse processo fica evidente se comparamos essa cifra com o total de população acrescida no período intercensal 1991/00 (um ano menos), que foi de 60.875 pessoas. Quanto à distribuição dessa população imigrante entre os municípios, 32,5\% foi para Paranaguá, $23 \%$ para Matinhos, $17,6 \%$ para Guaratuba e $15,2 \%$ para Pontal do Paraná, ficando os $12 \%$ restantes repartidos entre Antonina e os municípios rurais. Se observarmos a origem, $71,5 \%$ do total vêm do próprio estado, $37,2 \%$ de outros estados, e o $1,3 \%$ do exterior. Essa proporção varia um pouco no caso de Paranaguá, que recebeu mais imigrantes de outros estados $(37,3 \%)$, e no caso de Guaraqueçaba e de Pontal do Paraná, que receberam mais imigrantes do mesmo estado (aproximadamente $82 \%$ ) (quadro 7).

\section{Um pouco de história econômica}

Depois de ver a evolução demográfica do litoral nos últimos 30 anos e a magnitude do crescimento populacional de alguns dos municípios baseado na imigração, faz-se necessário buscar elementos de explicação na economia. Veremos, com um pouco de história econômica, como se chegou ao presente e depois a situação atual em números.

O litoral do Paraná, originariamente território dos índios tupi-guarani, foi colonizado pelos europeus a partir do século XVI, a partir de povoamentos no entorno da atual cidade de Paranaguá. A atividade econômica inicial foi a extração de ouro. A partir do século XVIII, desenvolveu-se a produção de arroz, com mão-de-obra escrava, que entrou em crise com a abolição da escravidão, no final do século XIX.

Pouco depois, com a demanda externa de banana, iniciou-se um ciclo de prosperidade que incentivou fluxos migratórios e processos de colonização, que, em vinte anos, duplicaram a população (1890/1910). A expansão do cultivo rapidamente ocupou as áreas agrícolas disponíveis, levando à intensificação do uso do solo. Isso acarretou perda de fertilidade, de produtividade e de rendimentos agrícolas, levando, no início da década dos 30 , a uma crise, reforçada pela concorrência do litoral paulista, que acabou com a exportação de banana. A produção de mandioca e de farinha e a extração e comercialização de palmito foram as alternativas ensaiadas, mas não permitiram superar a crise, o que levou a um progressivo esvaziamento das áreas rurais e a um fluxo migratório para a cidade de Paranaguá, cujo porto iniciava sua expansão. Em Morretes, a partir dos anos 50 , as atividades agrícolas e pastoris das serras foram abandonadas e os produtores passaram a ocupar as áreas úmidas das planícies, com pecuária e outros cultivos (RAYNAUT et al., 2002, p. 237-242). ${ }^{6}$

No final dos anos 60 , o panorama agrícola do litoral mudou em função de políticas fiscais que incentivaram as atividades agroflorestais, dando lugar à constituição de grandes latifúndios com exploração de madeira e palmito, cultivo de café e criação de gado. Complemen-

\section{QUADRO 5 - POPULAÇÃO E TAXAS MÉdIAS DE CRESCIMENTO ANUAL. BRASIL 1900-2000}

\begin{tabular}{|c|c|c|c|c|c|c|c|c|c|}
\hline Ano & 1900 & 1920 & 1940 & 1950 & 1960 & 1970 & 1980 & 1991 & 2000 \\
\hline População (000) & 17.438 & 27.500 & 41.165 & 51.942 & 70.070 & 93.139 & 119.003 & 146.825 & 179.799 \\
\hline Período intercensos & $1900 / 20$ & $1920 / 40$ & $1940 / 50$ & $1950 / 60$ & $1960 / 70$ & $1970 / 80$ & $1980 / 91$ & $1991 / 00$ & \\
\hline Taxa crescimento anual $(\%)$ & 2,1 & 2,0 & 2.4 & 3,0 & 2,9 & 2,5 & 1,9 & 1,6 & \\
\hline
\end{tabular}

FONTE: IBGE, Censos Demograficos 1900-2000, apud IBGE, 2002, p.15, e HOGAN, 1997, p. 373.

6 Ver in extenso em: MIGUEL, L. A. Formation, évolution et transformation d'un système agraire dans le Sud du Brésil (litoral nord de l'État du Paraná): une paysannerie face à une politique de protection de l'environnement: "Chronique d'une mort annoncée?". Paris, 1997. Thèse (Doctorat) - Institut National Agronomique Paris-Grignon. 
QUADRO 6 - ESTADO DO PARANÁ. 1950-1995 - TAXA DE FECUNDIDADE TOTAL POR SITUAÇÃO DE DOMICÍLIO.

\begin{tabular}{|c|c|c|c|c|c|}
\hline & \multicolumn{5}{|c|}{ Taxa de fecundidade total por situação de domicílio } \\
\cline { 2 - 6 } & $1950 / 60$ & $1960 / 70$ & $1970 / 80$ & $1980 / 90$ & $1991 / 95$ \\
\hline Paraná & 6,51 & 6,34 & 4,13 & 2,65 & 2,34 \\
Urbano & & 4,78 & 3,56 & 2,42 & 2,21 \\
Rural & & 7,51 & 5,23 & 3,46 & 2,95 \\
\hline
\end{tabular}

FONTE: Ipardes, 1997.

tarmente, melhorou-se o acesso à região com a construção de rodovias e estradas. Até início dos anos 80 , isso estimulou a compra de grandes extensões de terra, expulsando grande quantidade de agricultores, assim como o desmatamento de vastas áreas de floresta para a criação extensiva de gado, a intensificação da exploração do palmito e a agricultura mais intensiva em capital e uso de agroquímicos no sul (idem).

A partir dos anos 80, tentando conter a degradação ambiental, o governo implantou uma política de proteção que consistiu em criar unidades de conservação com variados regimes, ${ }^{7}$ intensificar a regulamentação de determinadas atividades agrícolas e pesqueiras e implementar incentivos para o plantio de palmito nativo. Essa política teve contrapartidas positivas e negativas. Por um lado, estimulou novas atividades e práticas agrícolas para compensar as limitações impostas, como a transformação da banana e da mandioca. Por outro, efeitos perversos como o aumento do uso de agroquímicos, a extração ilegal de palmito nativo, a introdução de espécies exóticas de palmito e o desmatamento clandestino (idem).

O município de Guaraqueçaba mantém um perfil decididamente agropecuário. Possui uma vasta área de Floresta Atlântica em alto grau de conservação e que nunca foi arrasada. Primeiro, escapou à expansão do cultivo de café que teve lugar no Rio e em São Paulo desde o século XIX até meados do XX, possivelmente pela baixa produtividade do solo, e posteriormente escapou à expansão do turismo praiano, pela inacessibilidade de suas praias. Está relativamente isolado, pois a estrada que o comunica a Antonina, desde os anos 70, não está totalmente asfaltada, sendo a via fluvial mais curta. A partir de $1985,83 \%$ do município ficou dentro da Área de Proteção Ambiental de Guaraqueçaba, que se estende ao município de Antonina. Os sucessivos ciclos de produtos agrícolas não conseguiram desenvolver a região por falta de competitividade com outras regiões com maior fertilidade do solo e mais investimentos. Atualmente, três são os produtos mais explorados comercialmente: banana, mandioca e gado, dos quais somente o gado encontra condições favoráveis de mercado, mas é a atividade mais impactante do meio natural. Também tem lugar a extração clandestina do palmito nativo, mas o aporte à renda familiar é pouco, seja pela progressiva escassez de palmeiras, seja pelas condições de comercialização, em que os intermediários ficam com a maior parte dos ganhos. As restrições ambientais legais, sem serem determinantes, coadjuvam na perda de competitividade e, no conjunto, tudo conflui na reprodução da pobreza (RODRIGUES et al, 2002/2003).

Em Morretes, a partir da década de 80, acutizaram-se os problemas de falta de competitividade da produção de mandioca e banana em função da forte concorrência de produtores de Guaratuba, Santa Catarina e São Paulo, que cultivam em terras mais férteis e têm melhor tecnologia. Constata-se a progressiva substituição do sistema tradicional empregado no cultivo desses produtos por sistemas de produção mais tecnificados aplicados ao cultivo de gengibre e olericultura, que tendem a se difundir para os demais municípios do litoral, especialmente para o norte. Estudos recentes questionam a sustentabilidade desses novos sistemas agrários, que geram diversos impactos negativos (MARCHIORO, ${ }^{8}$ apud RODRIGUES et al., 2002; 2003, p. 118-119).

Nos municípios de Antonina e Paranaguá, as cidades portuárias têm sido sempre o eixo central de suas economias. Desde o século XVIII, houve uma rivalidade entre elas pela função portuária principal do litoral do estado, disputando, em particular, a definição da conexão ao planalto curitibano com uma rodovia que permitisse a circulação adequada de mercadorias. $\mathrm{Na}$ época, e

7 Como, por exemplo, a antiga Área Especial de Interesse Turístico do Marumbi, a Estaçāo Ecológica de Guaraqueçaba (1982), a Área de Proteção Ambiental de Guaraqueçaba (1985), a antiga Área de Relevante Interesse Ecológico da Ilha do Pinheiro (1985) e o Parque Nacional de Superagüi (1989).

8 MARCHIORO, N. A sustentabilidade dos sistemas agrários no litoral doParaná: o caso de Morretes. Curitiba, 1999. Tese (Doutorado em Meio Ambiente e Desenvolvimento) - Universidade Federal do Paraná. p. 168. 
QUADRO 7 - MUNICÍPIOS DO LITORAL PARANAENSE - IMIGRAÇÃO INTRA-ESTADUAL, INTERESTADUAL E DO EXTERIOR, 1990-2000, POPULAÇÃO TOTAL ACRESCIDA 1991/00

\begin{tabular}{|c|c|c|c|c|c|c|}
\hline \multirow[b]{2}{*}{ Municípios } & \multicolumn{3}{|c|}{ ORIGEM DE IMIGRANTES } & \multicolumn{2}{|c|}{ TOTAL IMIGRANTES } & \multirow{2}{*}{$\begin{array}{c}\text { População total } \\
\text { acrescida 1991/2000 }\end{array}$} \\
\hline & INTRA-E & INTER-E & EXTERIOR & $Q$ & $\%$ & \\
\hline PORTUÁRIOS & 78 & +1 & 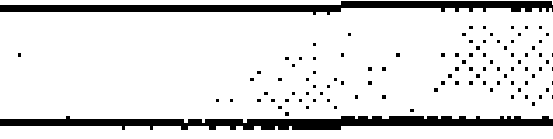 & 10 & & \\
\hline $\begin{array}{c}\text { Paranaguá } \\
\%\end{array}$ & $\begin{array}{c}9.971 \\
60,8\end{array}$ & $\begin{array}{l}6.114 \\
37,3\end{array}$ & $\begin{array}{l}303 \\
1,9\end{array}$ & $\begin{array}{l}\mathbf{1 6 . 3 8 9} \\
100\end{array}$ & 32,5 & 25.241 \\
\hline $\begin{array}{c}\text { Antonina } \\
\%\end{array}$ & $\begin{array}{l}1.676 \\
72,2\end{array}$ & $\begin{array}{l}597 \\
25,7\end{array}$ & $\begin{array}{l}49 \\
2,1\end{array}$ & $\begin{array}{c}2.322 \\
100\end{array}$ & 4,6 & 2.104 \\
\hline $\begin{array}{c}\text { RURAIS } \\
\text { Morretes } \\
\%\end{array}$ & $\begin{array}{c}9 \\
2.094 \\
79,0\end{array}$ & $\begin{array}{l}492 \\
18,6\end{array}$ & $\begin{array}{l}65 \\
2,4\end{array}$ & $\begin{array}{c}2.651 \\
100\end{array}$ & 5,3 & 2.140 \\
\hline $\begin{array}{c}\text { Guaraqueçaba } \\
\qquad \%\end{array}$ & $\begin{array}{l}731 \\
82,7\end{array}$ & $\begin{array}{l}153 \\
17,3\end{array}$ & $\begin{array}{l}0 \\
0\end{array}$ & $\begin{array}{l}884 \\
100\end{array}$ & 1,8 & 526 \\
\hline PRAIANO-TURIS. & -1 & & & & & : \\
\hline $\begin{array}{c}\text { Guaratuba } \\
\%\end{array}$ & $\begin{array}{l}6.595 \\
74,1 \\
\end{array}$ & $\begin{array}{r}2.277 \\
25,6\end{array}$ & $\begin{array}{r}28 \\
0,3 \\
\end{array}$ & $\begin{array}{l}8.901 \\
100 \\
\end{array}$ & 17,6 & 9.259 \\
\hline $\begin{array}{c}\text { Matinhos } \\
\%\end{array}$ & $\begin{array}{l}8.727 \\
75.1\end{array}$ & $\begin{array}{l}2.798 \\
24,1\end{array}$ & $\begin{array}{l}90 \\
0,8\end{array}$ & $\begin{array}{l}11.615 \\
100\end{array}$ & 23,0 & 12.859 \\
\hline $\begin{array}{c}\text { Pontal do PR } \\
\%\end{array}$ & $\begin{array}{c}6.301 \\
82,0\end{array}$ & $\begin{array}{l}1.274 \\
16,6\end{array}$ & $\begin{array}{r}111 \\
1,4\end{array}$ & $\begin{array}{c}7.685 \\
100\end{array}$ & 15,2 & 8.746 \\
\hline \multicolumn{7}{|l|}{ Subtotal } \\
\hline TOTAL & 36.096 & 13.705 & 647. & 50.447 & 100 & 60.875 \\
\hline & 71,5 & 27,2 & 1,3 & 100 & & \\
\hline
\end{tabular}

FONTE: IBGE, Ceııso 2000 (arquivo de microdados. tabulaçōes especiais)//pardes, 2003.

depois de mais de um século de disputa, ganhou Antonina e a rodovia foi concluída em 1872, seguindo o antigo caminho da Graciosa. Com essa conquista, a chegada da ferrovia e a construção do porto, Antonina atingiu um período de prosperidade entre 1930 e 1950, chegando a ser o primeiro grande porto da região e o quarto exportador do Brasil, com a erva-mate como o produto principal de exportação. Outras atividades contribuíram à prosperidade desse período, como a instalação de um complexo industrial que construiu armazéns e atracadouros e, mais tarde, na década de 60, a construção de uma usina, que exigiu uma obra de grande vulto. No início da década de 70 , com o avanço da produção de soja para exportação, os investimentos se desviaram para o porto de Paranaguá, que adequou a profundidade do canal para possibilitar o acesso de navios graneleiros. Isto levou à paralisação do porto de Antonina e ao fechamento da indústria referida. Com a finalização das obras da usina e a desativação do terminal ferroviário em 1977, iniciou-se uma fase de franca decadência do município, que se estende até hoje. Atualmente, além de atividades agrícolas, extrativismo e pesca tradicionais, desenvolvem-se algumas atividades industriais e uma atividade portuária tecnologicamente sofisticada, es- pecializada em alimentos perecíveis, que emprega muito pouca mão-de-obra, todo que resulta insuficiente para reverter a situação. Outro elemento que caracteriza o município de Antonina é a existência de três unidades de conservação que, do ponto de vista econômico, limitam a disponibilidade de recursos, especialmente para as atividades extrativistas tradicionais ${ }^{9}$ (MURATORI; PEDRO, 2002; MAIA, 2002).

No caso de Paranaguá, a cidade portuária concentra a maior parte da população e das atividades econômicas, entre as quais destaca-se a indústria química elaboradora de derivados da soja. O porto é o maior do Sul do Brasil, e o primeiro em exportação de grãos de América do Sul. Suas atividades estão fortemente atreladas à economia do estado: durante a década de 1960, destacava-se na exportação de café e madeira, refletindo o ciclo econômico vigente; com a implantação do corredor de exportação (operado na primeira etapa com embarques de milho), ganhou peso o segmento de granéis sólidos, que se consolidou com a introdução da cultura da soja. No final dos anos 60 e início dos anos 70 , com a expansão desse cultivo e a instalação das indústrias processadoras, os embarques de soja em grão e farelo passaram a ser a principal atividade, especializa-

9 Trata-se de parte da APA de Guaraqueçaba, da APA do Marumbi e do Parque Estadual Roberto Ribas Lange. 
ção que ampliou a área de influência do porto, servindo de saída da exportação para outros estados. Até 1997, a movimentação de farelo representava cerca de três vezes o volume da soja em grão, mas, a partir de uma modificação no regime de cargas tributárias, ganhou força a exportação de soja, que em 2000 chegou a superar a de farelo. Outra característica do porto de Paranaguá é que exporta muito mais do que importa, numa ordem de $70 \%$ do movimento geral. Atualmente, está em fase de expansão e diversificação para operar com carga geral conteinerizada, veículos e produtos líquidos, impulsionando investimentos, construção de instalações e atividades relacionadas (SUZUKI; WOSCH, 2000, p. 35-39).

Apesar dessa expansão e diversificação, o porto oferece cada vez menos empregos e sua influência econômica imediata, na cidade e na restante economia local, vai sendo cada vez menor. Trata-se de um processo verificado mundialmente, nos últimos 30 anos, a partir de uma série de inovações tecnológicas com consequiências nas operações diretas e na espacialização das atividades. Quanto às operações diretas, a tecnologia marítima diminui consideravelmente a duração da estadia dos navios nos portos e os novos métodos de transporte de mercadorias requerem menos mão-de-obra. Em relação à espacialização, favorecida pelas mudanças nos sistemas de transporte e pela introdução da informática, atividades como estocagem, embalagem, etiquetagem, segurança e comercialização, que até pouco tempo atrás eram realizadas nas cidades portuárias, podem ser realizadas fora delas. Daí que se fala do progressivo "divórcio" entre o porto e a cidade portuária. No caso de Paranaguá, isso resulta em diversos impactos que afetam a qualidade de vida da população, como desemprego, informalidade, pobreza, doenças por falta de alimento ou condições de higiene, ocupação de espaços públicos ou preservados, prostituição e delinquiência (GODOY, 2000; 2002; GERHARDT; NAZARENO, 2002).

Por sua parte, os municípios de Guaratuba, Matinhos e Pontal do Paraná não são alheios à evolução descrita das atividades agrárias, que em Guaratuba mantêm importante peso. A partir dos anos 50 do século XX, e mais intensamente nos anos 60 e 70, teve lugar o estabelecimento dos balneários ao longo da orla. Para isso, foi fundamental a estrutura viária que facilitou o acesso.
Conformaram-se primeiro os balneários do sul, possivelmente favorecidos pelo maior atrativo paisagístico, enquanto Pontal do Paraná ainda é a "fronteira" por onde continua avançando a ocupação com esse fim. Do ponto de vista econômico, salvo exceções, os setores que movimentam mais capital são o imobiliário e a construção civil, em meio da especulação característica da criação de espaços urbanos novos dirigidos às classes média e alta. O elemento crítico dessa dupla é a medida em que a qualidade dos espaços construídos confirme os investimentos imobiliários já realizados e incentive novos, o que muitas vezes está questionado pela "desordem urbana" decorrente da "fome" especulativa e da falta de capacidade financeira da administração pública para montar em tempo a infra-estrutura complementar. $\mathrm{O}$ outro setor importante é o comércio, que se destina principalmente a abastecer a indústria da construção e ao consumo dos turistas. O comércio dirigido aos turistas sofre da forte sazonalidade, em que o tempo de alta demanda é curto e nem sempre suficiente para arcar com os custos que são anuais, o que conspira contra a estabilidade e melhora dos investimentos, afeta a qualidade da oferta e sobe os preços. Por último, o setor de serviços tem a administração pública como o grande ofertante e o grande empregador, resultando chave para a qualidade de vida da população permanente.

\section{A economia atual em números}

Olhando o peso dos distintos municípios em relação ao conjunto, destaca-se que o município de Paranaguá detém, de maneira incontestável, a maior parte da atividade econômica da região. Essa centralidade econômica de Paranaguá é verificada em todos os indicadores: concentra 49,3\% dos estabelecimentos (2001), 66,3\% dos empregos (2001), 88,1\% do Valor Adicionado (VA) ${ }^{10}$ (2001), e $95,8 \%$ da arrecadação do Imposto sobre Circulação de Mercadorias e Serviços - ICMS (2002). Em termos de quantidade de estabelecimentos e de empregos, é seguido pelo conjunto de municípios praianos $(37,2 \%$ e $19,5 \%$, respectivamente), mas as atividades que os sustentam são inexpressivas em termos de VA e arrecadação do ICMS frente aos valores de Paranaguá (quadro 8).

10 O Valor Adicionado (VA) é a diferença entre os valores das operaçōes de saída e entrada de mercadorias e serviços sujeitos a ICMS, o que quer dizer que nāo têm incidência as atividades dos bancos, administração pública, serviços de saúde, educação, entre outros. Permite avaliar a estrutura produtiva pela da contribuição setorial e o grau de elaboração dos produtos, pois quanto maior for o VA, maior será o acréscimo de trabalho no produto. 
Mas afinal, que peso relativo tem a economia litorânea na economia estadual? Em termos de geração de riqueza, medida pelo Produto Interno Bruto (PIB) ou pelo VA, a participação é inexpressiva e está em declínio. Em 1997, a produção do litoral representava apenas $1,57 \%$ do PIB estadual. Paranaguá, que responde por mais de $4 / 5$ do valor adicionado da região e representava $3,43 \%$ do VA estadual em 1980, passou a representar $1,31 \%$ em 2000 (SUZUKI; WOSCH, 2000, p. 39; MOURA; WERNECK, 2000, p. 64; IPEA/IBGE/UNICAMP/IPARDES, 2000, p. 75).

Em relação à estrutura setorial, observada em termos do valor adicionado registrado no ano de 2001, a maior representatividade é do comércio e serviços, que somam $57,5 \%$ do total, mantendo uma proporção similar (em torno do 60\%) em Paranaguá e nos municípios praianos. Segue-lhe em importância o setor secundário ou industrial, que representa $40,9 \%$ do total, mantendo também uma proporção semelhante em Paranaguá, Morretes, Matinhos e Pontal do Paraná. Em Antonina, ganha uma proporção bem maior, de $75,3 \%$ do VA total. Finalmente, no conjunto, o setor primário ou agropecuário é totalmente marginal ( $1,6 \%$ do total), mas ganha importância nos municípios rurais, chegando a representar $25,8 \%$ do VA de Morretes e $12,4 \%$ do VA de Guaraqueçaba, e em menor medida em Guaratuba, onde representa $8,5 \%$ (quadro 9).

Em termos socioeconômicos, é mais significativa a quantidade de estabelecimentos e empregos gerados em cada setor. Nesse sentido, o peso se traslada fortemente ao setor de serviços, que detém $51,9 \%$ dos estabelecimentos registrados e $69,4 \%$ dos empregos, segundo dados do ano de 2001. ${ }^{11}$ Segue-lhe o comércio, com $36,7 \%$ dos estabelecimentos e $18,7 \%$ dos empregos. A indústria detém $8,9 \%$ dos estabelecimentos e $11,1 \%$ dos empregos e o setor agropecuário, apenas $2,5 \%$ dos estabelecimentos, e $0,8 \%$ dos empregos. Em termos da oferta de emprego em cada município, o setor de serviços oferece, em Antonina e Guaraqueçaba, em torno de $80 \%$ do total de empregos, e em Paranaguá e nos municípios praiano-turísticos, em torno de $70 \%$, descendo a $53,7 \%$ em Morretes. A atividade industrial oferece cerca de $13 \%$ dos empregos nos municípios portuários e em Morretes, descendo a aproximadamente $6 \%$ nos praiano-turísticos e a $3,3 \%$ em Guaraqueçaba. Por sua parte, o setor agropecuário oferece emprego, principalmente nos municípios rurais, mas, as cifras não são de grande peso: $14,6 \%$ em Morretes e 6,9\% em Guaraqueçaba (quadro $10)$.

No conjunto, o que se sobressai é o peso do setor de serviços na oferta de emprego, que seguramente tem o setor público como principal empregador em quase todos os municípios, com a possível exceção de Paranaguá, onde pode ganhar mais peso a atividade privada de serviços. As atividades produtivas agropecuárias e industriais são especialmente pouco significativas como empregadoras, enquanto a atividade comercial não oferece empregos em proporção à quantidade de estabelecimentos.

\section{Indagando sobre a questão das expectativas}

Embora não disponhamos de dados sobre os níveis de emprego/desemprego da população economicamente ativa, que permitiriam nos aproximar melhor da medida com que a economia litorânea pode estar respondendo ou não às expectativas de tantos imigrantes, temos os dados de nível da renda, que é um resultado especialmente significativo do que recolhe a população local das atividades econômicas existentes.

Em relação à renda nominal dos chefes de domicílio particular permanente no ano de $2000,{ }^{12}$ distinguem-se três situações. Na melhor, apresentada no município de Paranaguá e em menor medida em Matinhos e Pontal do Paraná, constatam-se os menores percentuais de chefes que recebem menos de 2 SM (34\%, em média) e os maiores percentuais que recebem mais de $10 \mathrm{SM}$ ( $8 \%$, em média). Em segundo lugar, a situação decididamente pior, presente no município de Guaraqueçaba, com os maiores percentuais que recebem menos de $1 \mathrm{SM}$ $(48,2 \%)$ e menos de $2 \mathrm{SM}(70,6 \%)$ e o menor percentual que recebe mais de $10 \mathrm{SM}(1,1 \%)$. E em terceiro lugar, em situação intermediária, os municípios de Antonina, Morretes e Guaratuba, com uma média percentual de $46 \%$ de chefes que recebem menos de $2 \mathrm{SM}$ e uma média percentual de $6 \%$ que recebe mais de $10 \mathrm{SM}$ (quadro 11 ).

11 A diferença tão expressiva do peso do setor de serviços em relação aos dados do VA se deve ao fato de que estes dados recuperam atividades dos bancos, administração pública, serviços de saúde e educação, entre outras, não contabilizadas no VA.

12 A renda nominal medida em quantidade de salários mínimos ( $\mathrm{SM}$ ), cujo valor era de $\mathrm{R} \$ 151,00$. 
de de aceder a espaços relativamente dignos para moradia.

\section{Conseqüiencias socioambientais do crescimento demográfico}

A leitura mais tradicional da questão ambiental entende os problemas ambientais como derivados da existência de muita população humana sobre um meio físico limitado. Consciente ou inconscientemente, nesse raciocínio está presente a idéia malthusiana ${ }^{13}$ de que o crescimento populacional (principalmente dos pobres, que são mais numerosos e se reproduzem mais) contraria as leis naturais e se choca com os limites físicos, gerando fome, de um lado, e problemas ambientais, do outro. Entretanto, distintas ciências sociais colaboram em discutir essa interpretação, com variados argumentos e dados.

Do ponto de vista da demografia, não se nega a importância da pressão populacional sobre o meio natural como eventual causa de impactos negativos, mas se coloca que não se pode analisar como um simples problema de tamanho grande frente a limites físicos absolutos. A questão está mais na densidade populacional e nos padrões de distribuição espacial, em relação às atividades que se desenvolvam e às características dos ecossistemas, que têm variadas capacidades de resiliência. De fato, dependendo das condições particulares, estes podem suportar populações muito grandes ou ser ameaçados por populações relativamente pequenas. Assim, para melhor trabalhar a relação população/ meio ambiente e captar a origem dos problemas ambientais, recomenda-se não trabalhar a população como um todo homogêneo, senão discriminar os segmentos e setores com condições significativas distintas e examinar como se localizam e agem, considerando as características ecológicas específicas. A partir disso será possível comprovar que as verdadeiras causas de problemas ambientais, muitas vezes adjudicadas ao crescimento demográfico e/ou aos movimentos migratórios, estão, antes, em problemas socioeconômicos, às vezes mais estruturais, às vezes mais conjunturais, reforçados por erros ou ausência de políticas públicas (HOGAN, 1997, p. 378-381; FOLADORI, 2001b, p. 123-126).

Seguindo este enfoque, uma equipe do Ipardes ${ }^{14}$ realizou em 2000 um estudo do crescimento populacional da ocupação urbana contínua do litoral (municípios de Paranaguá, Pontal do Paraná, Matinhos e Guaratuba), espacializando informações censitárias de 1991 e 1996,

QUADRO 9 - MUNICÍPIOS DO LITORAL PARANAENSE, 2001 - VALOR ADICIONADO POR SETORES ECONÔMICOS.

\begin{tabular}{|c|c|c|c|c|c|}
\hline \multirow[b]{2}{*}{ Municípios } & \multicolumn{4}{|c|}{ Valor adicionado $(\mathrm{R} \$ 1,00)$} & \multirow[t]{2}{*}{ TOTAL } \\
\hline & Primário & Secundário & Comércio & Serviços & \\
\hline PORTUÁRIOS & ॰ : & . & धँ ४ै। &  & \% \\
\hline Paranaguá & $\begin{array}{c}9.979 .052 \\
1,0\end{array}$ & $\begin{array}{c}407.576 .158 \\
40.5\end{array}$ & $\begin{array}{c}580.966 .833 \\
57.7\end{array}$ & $\begin{array}{c}8.161 .044 \\
0.8\end{array}$ & $\begin{array}{c}1.006 .683 .087 \\
100\end{array}$ \\
\hline Antonina & $\begin{array}{c}294.323 \\
1.0 \\
\end{array}$ & $\begin{array}{c}23.165 .336 \\
75.3 \\
\end{array}$ & $\begin{array}{c}6.959 .202 \\
22.6 \\
\end{array}$ & $\begin{array}{c}352.911 \\
1,1 \\
\end{array}$ & $\begin{array}{c}30.771 .772 \\
100 \\
\end{array}$ \\
\hline RURAIS & ৫ি_.. & োই & ब., প: : & 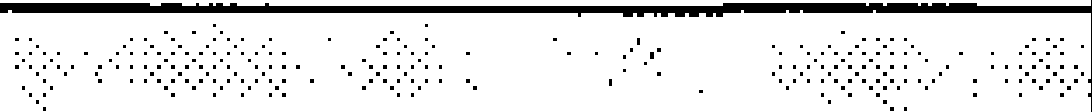 & धः। \\
\hline Morretes & $\begin{array}{c}4.952 .416 \\
25.8\end{array}$ & $\begin{array}{c}7.387 .967 \\
38.4\end{array}$ & $\begin{array}{c}5.794 .656 \\
30.2\end{array}$ & $\begin{array}{c}1.075 .081 \\
5.6\end{array}$ & $\begin{array}{c}19.210 .120 \\
100\end{array}$ \\
\hline Guaraqueçaba & $\begin{array}{c}156.222 \\
12.4 \\
\end{array}$ & $\begin{array}{c}531.248 \\
42,0 \\
\end{array}$ & $\begin{array}{c}562.765 \\
44,5 \\
\end{array}$ & $\begin{array}{c}13.991 \\
1.1\end{array}$ & $\begin{array}{c}1.264 .226 \\
100\end{array}$ \\
\hline PRAIANO-TUR & ए। & ब৫: & \%: & 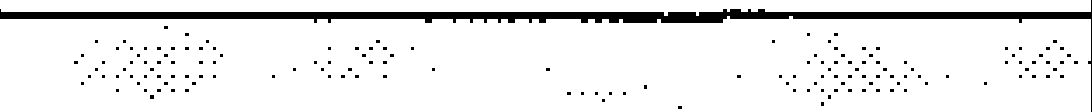 & is \\
\hline Guaratuba & $\begin{array}{c}3.359 .590 \\
8.5 \\
\end{array}$ & $\begin{array}{c}10.677 .421 \\
27.1\end{array}$ & $\begin{array}{c}23.779 .169 \\
60.4\end{array}$ & $\begin{array}{c}1.578 .055 \\
4.0\end{array}$ & $\begin{array}{c}39.394 .235 \\
100\end{array}$ \\
\hline $\begin{array}{l}\text { Matinhlos (2000) } \\
\text { Pontal do Paraná }\end{array}$ & $\begin{array}{c}14.480 \\
0.05 \\
40.469 \\
0.2 \\
\end{array}$ & $\begin{array}{c}11.157 .697 \\
40,2 \\
7.316 .993 \\
40.2 \\
\end{array}$ & $\begin{array}{c}10.496 .689 \\
57,8\end{array}$ & $\begin{array}{c}330.074 \\
1.8 \\
\end{array}$ & $\begin{array}{c}27.780 .572 \\
100 \\
18.184 .225 \\
100\end{array}$ \\
\hline TOTAL & 18.796 .552 & $\mathbf{4 6 7 . 8 1 2 . 8 2 0}$ & 645.167 .709 & 11.511 .156 & 1.143 .288 .237 \\
\hline 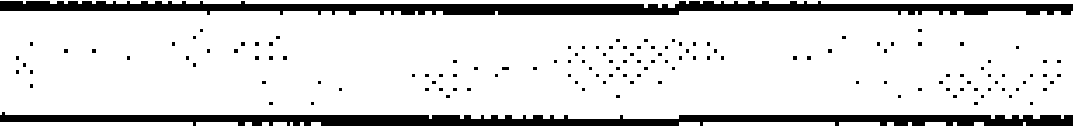 & 1,6 & ৫: & 56,4 & $\%$ & 100 \\
\hline
\end{tabular}

FONTE: SEFA, apud IPARDES, 2003.

NOTA: Dados sujeitos a reavaliações pela fonte.

No caso de Matinhos a informação é do ano 2000.

O valor adicionado pelo comércio e os serviços em Matinhos não está diferenciado ná fonte. Nos cálculos, somamos a cifráa na coluna de comércio.

13 Colocada pelo economista inglês Malthus no século XIX e retomada por alguns ecologistas no século XX.

14 Ver DESCHAMPS e KLEINKE (2000) e MOURA e WERNECK (2000). 
de forma a identificar os padrões socioespaciais presentes.

Deschamps e Kleinke (2000), com base na informação por setores censitários, localizaram espacialmente a distribuição do crescimento populacional e a participação de imigrantes nele, identificando o nível de instrução do chefe de domicílio migrante. A repetição de setores censitários com crescimento populacional e perfil de moradores similares, cruzando essas informações, configurou um padrão socioespacial, posteriormente confirmado pela aplicação da técnica chamada de "leitura do espaço". ${ }^{15}$

Os setores censitários que apresentaram as maiores taxas de crescimento encontram-se majoritariamente em áreas menos valorizadas ou próximas às ocupações informais, principalmente opostas à área próxima à praia, onde predominam as residências de veraneio. ${ }^{16}$ Os maiores volumes de imigrantes localizavam-se nas áreas de maiores taxas de crescimento e de menor renda. ${ }^{17}$ Por sua vez, o nível de escolaridade dos chefes de domicílio imigrantes mostra maior proporção de pessoas com menos anos de escolaridade nas áreas mais carentes, em termos de infra-estrutura e serviços urbanos, e com maiores taxas de crescimento. O cruzamento destas três variáveis, complementado com a leitura do espaço, indicou a possível conformação de bolsões de pobreza, seguindo estes padrões:

- áreas de ocupação recente, com as taxas mais elevadas de crescimento populacional, os maiores volumes de imigrantes e os menores niveis de escolaridade dos chefes - em Guaratuba, a região de Piçarras e pequenas ocupações dispersas nas áreas de expansão

\section{QUADRO 10 - MUNICÍPIOS DO LITORAL PARANAENSE, 2001 - ESTABELECIMENTOS E EMPREGOS POR SETORES ECONÔMICOS}

\begin{tabular}{|c|c|c|c|c|c|c|c|c|c|c|}
\hline \multirow[b]{2}{*}{ Municípios } & \multicolumn{2}{|c|}{ Agropecuária } & \multicolumn{2}{|c|}{ Indústria } & \multicolumn{2}{|c|}{ Comércio } & \multicolumn{2}{|c|}{ Serviços } & \multicolumn{2}{|c|}{ Total } \\
\hline & Estabelec & Empregos & Estabelec. & Empregos & Estabelec. & Empregos & Estabelec. & Empregos & Estabelec. & Empregos \\
\hline PORTUÁRIOS & \multicolumn{2}{|c|}{ 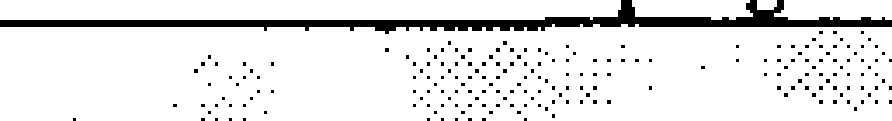 } & \multicolumn{2}{|c|}{ ह : } & \multicolumn{2}{|c|}{ ९ै: ४ न } & \multicolumn{2}{|c|}{ 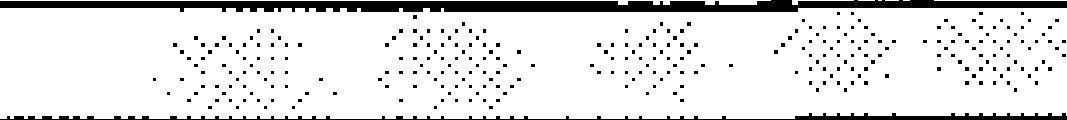 } & \multicolumn{2}{|c|}{$\begin{array}{llll}9 & 8 & \cdots\end{array}$} \\
\hline \multirow[t]{2}{*}{ Paranaguá } & 7 & 18 & 163 & 2.821 & 788 & 4.293 & 927 & 15.590 & 1.885 & 22.722 \\
\hline & 0.4 & 0,1 & 8,6 & 12,4 & 41,8 & 18,9 & 49,2 & 68,6 & 100 & 100 \\
\hline \multirow[t]{2}{*}{ Antonina } & 17 & 34 & 29 & 398 & 68 & 183 & 126 & 2.570 & 240 & 3.185 \\
\hline & 7.1 & 1,1 & 12,1 & 12,5 & 28,3 & 5,7 & 52,5 & 80,7 & 100 & 100 \\
\hline RURAIS & ४ & & $\cdots$ & ब: & & & $\overline{6}$ & & 6 & ध \% \\
\hline \multirow{2}{*}{ Morretes } & 52 & 180 & 20 & 166 & 72 & 226 & 85 & 665 & 229 & 1.237 \\
\hline & 22.8 & 14.6 & 8,7 & 13,4 & 31,4 & 18,3 & 37,1 & 53,7 & 100 & 100 \\
\hline \multirow{2}{*}{$\begin{array}{c}\text { Guaraqueçaba } \\
\text { PRAIANO-TURIST. }\end{array}$} & 11 & 31 & 4 & 15 & 16 & 36 & 14 & 370 & 45 & 452 \\
\hline & 24,4 & 6,9 & 8,9 & 3,3 & 35,6 & 8,0 & 31,1 & 81,8 & 100 & 100 \\
\hline \multirow[t]{2}{*}{ Guaratuba } & 5 & 8 & 50 & 172 & 200 & 788 & 249 & 2.032 & 504 & 3.000 \\
\hline & 1,0 & 0,3 & 9.9 & 5,7 & 39,7 & 26,3 & 49,4 & 67,7 & 100 & 100 \\
\hline \multirow[t]{2}{*}{ Matinhos } & 1 & 5 & 45 & 156 & 137 & 632 & 478 & 1.833 & 661 & 2.626 \\
\hline & 0,2 & 0,2 & 6,8 & 5,9 & 20,7 & 24,1 & 72,3 & 69,8 & 100 & 100 \\
\hline \multirow[t]{2}{*}{ Pontal do Paraná } & -- & -- & 28 & 70 & 123 & 258 & 107 & 711 & 258 & 1.039 \\
\hline & -- & -- & 10,9 & 6,7 & 47,7 & 24,8 & 41,4 & 68,5 & 100 & 100 \\
\hline \multirow[t]{2}{*}{ TOTAL } & 93 & 276 & 339 & 3.798 & 1.404 & 6.416 & 1.986 & 23.771 & 3.822 & 34.261 \\
\hline & 2,5 & 0,8 & 8.9 & 11,1 & 36,7 & 18,7 & 51,9 & 69,4 ॠ & 100 & 100 \\
\hline
\end{tabular}

FONTE: MTB, apud Ipardes, 2003.

NOTA: No caso de Matinhos, a informação é do ano 1999.

15 Trata-se de uma técnica de estudo da ocupação e uso do solo que integra o estudo de imagens satélite, dados secundários georreferenciados, observação direta e entrevistas com representantes do poder público local, do mercado imobiliário, pessoas vinculadas à gestão urbana e moradores escolhidos aleatoriamente (ibid DESCHAMPS e KLEINKE, 2000, p. 47).

16 Acompanham, em Matinhos, a rodovia PR 412, as estradas PR 508 (Alexandra/Matinhos), a PR 407 (BR 277/Praia de Leste) e, em Paranaguá, a BR 277 e PR 407; os fundos de vales de cursos de água, próximos ao rio Boguaçu Mirim (Guaratuba), áreas ambientalmente vulneráveis como encostas (Matinhos), restingas e mangues (Pontal do Paraná e Paranaguá) e proximidades do "lixão" de Pontal do Paraná (ibid, p. 52).

17 A maior concentração se apresentava em Guaratuba - na região de expansão (Coroados) e nos bairros centrais de baixa renda (Piçarras e Carvoeiro) -, em Matinhos, nas bordas das encostas (Vila Nova e Tabuleiro), e nas margens da rodovia que vem de Alexandra. Em Pontal e em Paranaguá, o volume de imigrantes era menor, possivelmente em função de Pontal estar ainda em expansão e de Paranaguá ter um perfil diferente dos demais municípios considerados (ld.). 
urbana; em Matinhos, nas encostas da periferia de Caiobá; em Pontal do Paraná, nas áreas marginais à rodovia de acesso ao município;

- áreas de ocupação recente, com elevado crescimento populacional, baixo volume de imigrantes e elevada proporção de chefes com baixa escolaridade em Pontal do Paraná, ocupações próximas aos principais balneários e outras dispersas ao longo da costa; em Paranaguá, ocupações nas margens da PR 407;

- áreas de ocupação mais consolidada, elevado crescimento populacional, razoável volume de imigrantes, e proporção intermediária de chefes com baixa escolaridade - em Guaratuba, Nereidas e Carvoeiro; em Matinhos, ocupações nas margens da rodovia de acesso e outras na área de expansão urbana; em Pontal do Paraná, ocupações nas cercanias do "lixão"; e em Paranaguá, Jardim Iguaçu, São Carlos e Ipê.

- áreas de ocupação mais consolidada, elevado crescimento populacional, inexpressivo volume de imigrantes e reduzida proporção de chefes com baixa escolaridade - em Paranaguá, principalmente ao longo da BR 277, provavelmente decorrente de migração intra-urbana (DESCHAMPS; KLEINKE, 2000, p. 52-53) (quadro 12).

Em síntese, nas áreas de ocupação recente, o mais alto crescimento populacional está associado à mais alta presença de imigrantes, que, por sua vez, apresentam a mais alta proporção de baixa instrução, que, neste país, é um indicador de pobreza e, seguramente, de baixa quali- ficação laboral. Do ponto de vista da distribuição espacial, reproduzem-se padrões de segmentação e ocupação irregular de áreas ambientalmente vulneráveis.

$\mathrm{Na}$ área turística, essa nova realidade coloca desafios particulares para articular a otimização desse perfil com as demandas da crescente população permanente, fundamentalmente pobre. Do contrário, os balneários podem somar, aos problemas ambientais gerados pela ocupação e uso turístico, uma progressiva desqualificação pela conformação espacial, degradada e conflitante, dessa origem.

\section{Conclusões}

O litoral paranaense é um conjunto de realidades socioeconômicas distintas, resultado de processos históricos com data, nível e alcance diferentes, cuja compreensão requer pesquisa específica para desvelar as forças que têm confluído na estruturação socioespacial atual e para ter elementos para agir daqui para a frente.

As atividades econômicas com dinâmicas mais pujantes, fundamentalmente as ligadas ao porto de Paranaguá e ao turismo praiano, não revertem proporcionalmente em benefícios para a população permanente. Sua lógica responde e beneficia mais a setores externos à região: no caso do porto, aos produtores, exportadores e a todos os setores vinculados, de vários estados; e

QUADRO 11 - DISTRIBUIÇÃO DE FREQÜÊNCIAS DO RENDIMENTO NOMINAL MENSAL DOS CHEFES DE DOMICÍlIOS PARTICULARES PERMANENTES. PARANÁ, RMC E MUNICÍPIOS DO LITORAL PARANAENSE. 2000

\begin{tabular}{|c|c|c|c|c|c|c|c|c|}
\hline & \multicolumn{7}{|c|}{ RENDIMENTO NOMINAL MENSAL $($ SM $)\left({ }^{*}\right)$} & \multirow{2}{*}{$\begin{array}{c}\text { Sem rend. } \\
(* *)\end{array}$} \\
\hline & Até 1 & 1.2 & $2-3$ & 3-5 & $5-10$ & $10-20$ & +20 & \\
\hline PARANÁ & 19,6 & 22,3 & 13,2 & 15,1 & 13,8 & 6,2 & 3,4 & 6,4 \\
\hline RMIC & 9,5 & 16,4 & 13,8 & 18.6 & 18.7 & 9.6 & 6,1 & 7,3 \\
\hline \multicolumn{9}{|l|}{$\begin{array}{l}\text { Municípios do } \\
\text { Litoral do PR }\end{array}$} \\
\hline Portuários & & & & & & & & n: \\
\hline Parantaguá & 13,0 & 19,7 & 13,8 & 19,5 & 18,3 & 6,5 & 2,9 & 6,2 \\
\hline Antonina & 26.3 & 22,2 & 12,1 & 12,8 & 11.4 & 4,1 & 1,2 & 9,8 \\
\hline Rurais & & & & & & & & \\
\hline Morretes & 23,7 & 25,9 & 11,4 & 13,9 & 11,1 & 4,2 & 1,5 & 8,4 \\
\hline Guaraqueçaba & 48,2 & 22,4 & 7,3 & 7,6 & 4,7 & 0.7 & 0,4 & 8,7 \\
\hline Praiano-turísticos & & & & & & & & \\
\hline Guaratuba & 17,0 & 22,8 & 14,7 & 17,4 & 13.0 & 4,3 & 1,6 & 9,1 \\
\hline Matinhos & 12,3 & 21,3 & 17,1 & 19,1 & 14,8 & 5,0 & 1,8 & 8,8 \\
\hline Pontal do Paraná & 13.9 & 20,5 & 14,3 & 16,7 & 14.7 & 5,2 & 1,5 & 13,2 \\
\hline
\end{tabular}

FONTE: IBGE, Censo 2000.

NOTA: (*) O valor do Sálário Mínimo (SM) considerado é de $R \$ 151,00$.

${ }^{* *}$ A categoria "Sem rendimento" inclui as pessoas que receberam somente em beneficios. 
QUADRO 12 - OCUPAÇÃO URBANA CONTÍNUA DO LITORAL PARANAENSE (1996)

BOLSÕES DE POBREZA EM ÁREAS COM ELEVADA TAXA DE CRESCIMENTO POPULACIONAL SEGUNDO VOLUME DE IMIGRANTES E PROPORÇÃO DE MIGRANTES COM BAIXA ESCOLARIDADE.

\begin{tabular}{|c|c|c|c|c|c|c|c|c|c|}
\hline \multirow{2}{*}{ Ocupação } & \multicolumn{4}{|c|}{ Volume de população imigrante } & \multicolumn{4}{|c|}{$\begin{array}{l}\text { Proporção de imigrantes chefes com baixa } \\
\text { instruçãa }\end{array}$} & \multirow{2}{*}{ LOCALIZAÇÃO } \\
\hline & $\begin{array}{l}\text { Muito } \\
\text { Baixo }\end{array}$ & Baixo & Meio & Alto & Baixa & Meia & Alta & $\begin{array}{c}\text { Muito } \\
\text { alta }\end{array}$ & \\
\hline \multirow[t]{2}{*}{ Recente } & & & & $\mathrm{x}$ & & & & $\mathrm{x}$ & $\begin{array}{l}\text { Guaratuba. Regiāo de Piçarras e } \\
\text { pequenas ocupacấes dispersas nas } \\
\text { áreas de expansão urbana. } \\
\text { Matinhos. Encostas na periferia } \\
\text { de Caiobá. } \\
\text { Pontal do Paraná. Áreas } \\
\text { marginais à rodovia de acesso ao } \\
\text { município. }\end{array}$ \\
\hline & & $\mathrm{x}$ & & & & & $\mathrm{x}$ & & $\begin{array}{l}\text { Pontal do Paraná. Ocupações } \\
\text { próximas aos principais balneários } \\
\text { e outras ocupaçôes dispersas ao } \\
\text { longo da costa. } \\
\text { Paranaguá. Densas ocupaçôes } \\
\text { nas margens da PR 407. }\end{array}$ \\
\hline \multirow[t]{2}{*}{$\begin{array}{c}\text { Mais } \\
\text { Consolidada }\end{array}$} & & & $\mathrm{x}$ & & & $\mathrm{X}$ & & & $\begin{array}{l}\text { Guaratuba. Nereidas e Carvoeiro } \\
\text { Matinhos. Margens da rodovia de } \\
\text { acesso. Outras dispersas naa área } \\
\text { de expansão urbana. } \\
\text { Pontal do Paraná. Cercanias do } \\
\text { "lixão" } \\
\text { Paranaguá. Jardim Iguaçu, São } \\
\text { Carlos e Ipê. }\end{array}$ \\
\hline & $\mathrm{x}$ & & & & $\mathrm{X}$ & & & & Paranaguá. Ao long̨o da BR 277. \\
\hline
\end{tabular}

FONTE: Elaboração própria com base em DESCHAMPS; KLEINKE (2000, P.53).

Dados do IBGE, Censo 1991, e Contagem Populacional 1996; e Leitura do espaço (2000).

no caso do turismo, além dos setores econômicos que operam em nível local, os beneficiários principais são os turistas, que pertencem à classe média e alta, fundamentalmente de Curitiba. Nesse sentido, a população permanente vive mais na expectativa do que vem de fora, que do que ela mesma pode gerar, o que em grande medida a deixa impotente para buscar caminhos de melhoria.

A grande afluência de imigrantes, que explica o crescimento vertiginoso da população nos últimos 30 anos, dirige-se fundamentalmente aos municípios onde acontecem essas atividades em expansão. Embora, por distintas razões, não haja uma oferta de empregos proporcional a essa expansão, em relação à falta de oportunidades nos lugares de origem e à saturação de outras opções, as expectativas dos imigrantes não estariam fundamentalmente decepcionadas, explicando a persistência desse fluxo. Isso não implica a reversão das desigualdades e dos níveis de pobreza que são característicos do país e do estado, mas possivelmente um espaço com menos concorrentes e com mais possibilidades de atenção de políticas públicas que nos lugares de origem ou os alternativos.
Os espaços ocupados por essa população imigrante pobre muitas vezes são juridicamente irregulares e se localizam em áreas ambientalmente frágeis, gerando problemas de diversa índole, e expondo as pessoas a diferentes riscos. Trata-se de um fato emergencial decorrente do encontro da pobreza com a propriedade privada do solo, em que os que podem pagar ocupam os espaços "adequados" ou melhores. Nesta sociedade, isso não tem solução estrutural, geral e permanente, senão pontual e temporal e que depende de resoluções políticas. Neste caso, é bom relativizar esse problema, que poderíamos chamar de "contaminação e depredação da pobreza" com o problema, possivelmente maior, de "contaminação e depredação da riqueza" derivado da ocupação do solo com fins turísticos. E, na hora de pensar soluções e políticas, além de pôr mais ênfase em disciplinar as ações dos ricos é necessário favorecer a diminuição ou erradicação da pobreza, já que ela coloca a maioria da população em condição de insustentabilidade da própria vida. 
ANDRIGUETTO, J. M.; MARCHIORO, N. P. X. Diagnóstico e problemática para a pesquisa. In: REYNAUT, C. et al. (Ed.). Desenvolvimento \& meio ambiente. Em busca da interdisciplinaridade. Pesquisas urbanas e rurais. Curitiba: Ed. UFPR, 2002. p. 159-194.

DESCHAMPS, M. V.; KLEINKE, M. L. U. Os fluxos migratórios e as mudanças socioespaciais na ocupação contínua litorânea do Paraná. Revista Paranaense de Desenvolvimento, Curitiba, n. 99, p. 45-59, jul./dez. 2000

FOLADORI, G. Limites do desenvolvimento sustentável. São Paulo: Imprensa Oficial, $2001 \mathrm{~b}$.

FUNDAÇÃO DA UNIVERSIDADE FEDERAL DO PARANÁ - FUNPAR. Diagnóstico do município de Pontal do Paraná, subsídio para elaboração do Plano Diretor. Curitiba: FUNPAR, 1999. v. 1.

GERHARDT, T. E.; NAZARENO, E. R. Diálogo entre epidemiologia e a antropologia nas questões de saúde. In: REYNAUT, C. et al. (Ed.). Desenvolvimento \& Meio ambien$t e$. Em busca da interdisciplinaridade. Pesquisas urbanas e rurais. Curitiba: Ed. UFPR, 2002. p. 103-125.

GODOY, A. M. G. Reestruturação produtiva e polarização do mercado de trabalho em Paranaguá-PR. Revista Paranaense de Desenvolvimento, Curitiba, n. 99, p. 5-25, jul./dez. 2000.

Os impactos sócio-econômicos das transformações no sistema portuário. In: REYNAUT, C. et al. (Ed.). Desenvolvimento \& Meio ambiente. Em busca da interdisciplinaridade. Pesquisas urbanas e rurais. Curitiba: Ed. UFPR, 2002. p. 4362.

HOGAN, D. J. Mudança ambiental e o novo regime demográfico. In: CAVALCANTI, C. (Org.). Meio Ambiente, desenvolvimento sustentável e políticas públicas. São Paulo: Cortez, 1997. p. 369-383.

IBGE. Censo Demográfico 2000. Características da população e dos domicílios. Resultados do universo. Rio de Janeiro: IBGE, 2001.

Censo Demográfico 2000. Agregado de Setores Censitários dos resultados do universo. Rio de Janeiro: IBGE, 2002a.

Indicadores de desenvolvimento sustentável. Brasil 2002. Rio de Janeiro: IBGE, 2002b.

Censo 2000. Arquivo de microdados. Tabulações especiais. Curitiba: Ipardes, 2003.
IPEA; IBGE; UNICAMP/IE/NESUR; IPARDES. Caracterização e tendências da rede urbana do Brasil: redes urbanas regionais. Sul. Brasília: IPEA, 2000.

IPARDES. Dinâmica demográfica regional recente da Região Sul. Curitiba: Ipardes, 1997.

Paraná. Projeções das populações municipais por sexo e idade, 2000 a 2010. Curitiba: Ipardes, 2000.

Caderno estatístico. Municípios de Antonina, Guaraqueçaba, Guaratuba, Matinhos, Morretes, Paranaguá, Pontal do Sul. Curitiba: Ipardes, 2003.

MAIA, D. M. Antonina: Cooperativa Serramar. Um aprendizado compartilhado. In: JUSTINO, M. J. (Org.). Incubadora tecnológica de cooperativas populares: a experiência da UFPR. Curitiba: UFPR/Proec, 2002. p. 57-65.

MARCHIORO, N. A sustentabilidade dos sistemas agrários. In: LIMA, R. E.; NEGRELLE, R. B. (Org.). Meio Ambiente e Desenvolvimento no Litoral do Paraná: diagnóstico. Curitiba: Ed. UFPR, 1998. p. 65-71.

MOURA, R.; WERNECK, D. Z. Ocupação contínua litorânea do Paraná: uma leitura do espaço. Revista Paranaense de Desenvolvimento, Curitiba, n. 99, p. 61-82, jul./dez. 2000.

MURATORI, A. M.; PEDRO, C. R. Desenvolvimento humano sustentável e cooperativismo popular no Município de Antonina, Paraná. In: JUSTINO, M. J. (Org.). Incubadora tecnológica de cooperativas populares: a experiência da UFPR. Curitiba: UFPR/Proec, 2002. p. 45-55.

SINGER, P. Economia política da urbanização. São Paulo: Contexto, 1998.

SUZUKI, J. T.; WOSCH, L. F. O. As transformações da infraestrutura de transporte e o porto de Paranaguá. Revista Paranaense de Desenvolvimento, Curitiba, n. 99, p. 27-43, jul./dez. 2000.

RAYNAUT, C.; ZANONI, M.; LANA, P. O desenvolvimento sustentável regional: o que proteger? Quem desenvolver? In: REYNAUT, C. et al. (Ed.). Desenvolvimento \& Meio ambiente. Em busca da interdisciplinaridade. Pesquisas urbanas e rurais. Curitiba: Ed. UFPR, 2002. p. 235-248.

RODRIGUES, A. et al. É correto pensar a sustentabilidade a nível local? Uma análise metodológica de um estudo de caso em uma área de proteção ambiental no litoral sul do Brasil. Ambiente e Sociedade, Campinas, v. 5, n. 2, p. 109127, ago./dez. 2002; v. 6, n. 1, jan./jul. 2003. 